\title{
Osteometry and Morphology of the Human Fibula: A South African Study
}

\author{
Osteometría y Morfología de la Fíbula Humana: Un Estudio de Sudáfrica
}

Naidoo, N..; Ishwarkumar, S..; Lazarus, L.*; Pillay, P.* \& Satyapal, K. S.*

NAIDOO, N.; ISHWARKUMAR, S.; LAZARUS, L.; PILLAY, P. \& SATYAPAL, K. S. Osteometry and morphology of the human fibula: A South African study. Int. J. Morphol., 33(3):1071-1077, 2015.

SUMMARY: Recent studies have regarded the fibula flap as the benchmark for the reconstruction and treatment of compound wounds and lesions. Owing to its postero-lateral location within the leg, the application of the fibula flap is deemed aesthetically advantageous as the donor scar can be easily hidden. Since the fibula is anatomically characterized by a shaft and two extremities, this study aimed to investigate the nutrient foramen morphology and the relative fibular osteometry. Osteometric and morphological evaluation of 104 dry human fibulae, representing male and female individuals of the Black and Caucasian population groups that are native to South Africa, were conducted (Age range: 15 - 81 years old). The presence of single, double and six nutrient foramina were noted. A total of fifteen different locations of the nutrient foramen relative to the fibular surfaces, margins and component parts were identified. In addition to several other osteometric parameters, the mean fibular length $(\mathrm{mm})$ and diameter of the nutrient foramina (mm) were [(male:

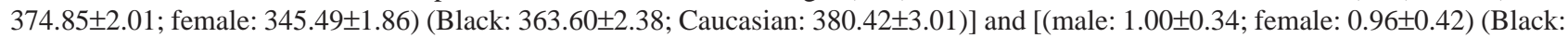
$0.98 \pm 0.37$; Caucasian: $1.11 \pm 0.27)$ ], respectively. In light of the lack of osteometric data regarding destabilization and subsequent reconstruction of the talocrural joint, the relative sides and angles of the irregular triangular talar facet were quantified. Due to the correlation of the respective fibular parameters with age, sex and races, the focus of this study was extensive in comparison to previous studies. The recorded statistically significant differences for age, sex and race may suggest a South African standardization of those demographic factors with the relevant fibular parameters. Furthermore, the location of nutrient foramina within the fibular shaft may assist with the mapping and development of simple classification schemes for the harvesting of fibular grafts.

KEY WORDS: Fibula; Osteometry; Morphology; Nutrient foramen.

\section{INTRODUCTION}

The fibula, better known as the calf bone, was introduced into anatomical nomenclature by Versalius during the sixteenth century (Skinner, 1961; Gray, 2000). As the slender lateral bone of the leg, the fibula is characterized by a proximal head, a twisted shaft and a distal lateral malleolus (Standring, 2008; Moore et al., 2010).

The growing popularity of fibula flap transfer and the advent of micro-vascular surgery have specified the fibula flap as the workhorse flap in mandibular reconstruction (Taylor et al., 1975; Fernandes, 2006). Since the fibula group is considered to present with fewer complications at the respective donor and recipient sites than any other bone group and the distant location of the fibula from the head allows for a concurrent two-team approach, the fibula is extensively used in orthopaedic and plastic surgery (Matsuura et al., 1999; Fernandes; Winters, 2007).
As height presents as a major anthropometric component in the nutritional assessment of an individual, newly-developed linear regression models have incorporated the fibula length as a measure of stature in convalescent homes and hospitals as it is infrequently affected by osteoporotic fractures in old age (Auyeung et al., 2009). Furthermore, the inconsistency in leg length is especially important in the management of cases presenting with a deficiency of the fibula because the absence of the bone is often accompanied by other leg malformations (Achterman \& Kalamchi, 1979).

The vascular supply to long bones, particularly the fibula, is a central factor in ensuring the success of orthopaedic procedures (Pereira et al., 2011). Despite the classical description of the nutrient foramina, there appears to be much variability regarding their location (Matsuura

\footnotetext{
* Department of Clinical Anatomy, School of Laboratory Medicine and Medical Sciences, College of Health Sciences, University of KwaZulu-Natal, Durban, South Africa.
} 
et al.). Furthermore, since there is much uncertainty in the exact location of the nutrient foramina within the relative fibular surfaces, an understanding of the regional distribution of nutrient foramina is necessary to avoid injury to such regions during surgery in order to stimulate fracture healing (Shimada \& Yoshimura, 1981; Chen et al., 1981; Matsuura et al.; Pereira et $a l$.$) .$

Despite the lack of a weight-bearing functionality and the non-participation in the knee joint, the fibula plays a pivotal role in the tibiofibular syndesmosis for the stabilization of the talocrural joint (Taser et al., 2009; Moore et al.). Pre- and postoperative evaluation of talocrural fracture patterns are dependent on the distal fibular anatomy (Taser et al.).

Therefore, in view of the widespread clinical relevance the purpose of this study was to investigate the osteometry and morphology of the human fibula within a South African population group.

\section{MATERIAL AND METHOD}

This study comprised the osteometric and morphological evaluation of 104 randomly selected, unpaired dry fibulae obtained from the existing osteological bank at the Discipline of Clinical Anatomy, School of Laboratory Medicine and Medical Sciences at the University of KwaZulu-Natal $(n=104)$. Ethical clearance was granted by the relevant institutional authority (Ethics number: BE 036/14).

The sample series consisted of 63 males and 41 females with an age range of 15 to 81 years old from the Black (101) and Caucasian (3) South African population groups. Fibulae displaying evidence of previous fracture and/or fragmented heads or malleoli were excluded from this study. All osteometric parameters were quantified through the use of a digital caliper (Mitutoyo Digimatic Caliper, Model No. CD8 " C). The relative angles of the irregular triangular talar facet were estimated via the use of an online web calculator (www.handymath.com).

Statistical analysis, which compared for the levels of significance between the fibular parameters and age, sex and race was conducted using the Statistical Package for Social Sciences, version 21.0 (SPSS Inc., Chicago, Illinois, USA). A p value of $<0.05$ was considered to be statistically significant.

\section{RESULTS}

Morphology: Nutrient Foramina. The respective incidences of the relative fibular nutrient foramina parameters were recorded: (i) Number of nutrient foramina: (a) One [(male: $53.8 \%$; female: 39.4\%) (Black: 91.3\%; Caucasian: $1.9 \%$ )]; (b) Two [(male: $5.8 \%$ only) (Black: 4.8\%; Caucasian: 1.0\%)]; (c) Six [(male: 53.8\%; female: 39.4\%) (Black: 91.3\%; Caucasian: 1.9\%)] (Figs. 1, 2, 3 and 4A-B; Table I); (ii) Location of nutrient foramina: (a) Posterior surface, middle 1/3 shaft [(male: 30.8\%; female: 15.4\%) (Black: 43.3\%; Caucasian: $2.9 \%$ )]; (b) Posterior surface, proximal 1/3 shaft [(male: 4.8\%; female: $1.0 \%$ ) (Black: 5.8\% only)]; (c) Medial margin of posterior surface, middle $1 / 3$ shaft [(female: $1.9 \%$ only) (Black: $1.9 \%$ only)]; (d) Lateral surface, middle $1 / 3$ shaft [(male: $2.9 \%$; female: $1.0 \%$ ) (Black: $3.8 \%$ only)]; (e) Medial margin of posterior surface, distal 1/3 shaft [(male: $1.0 \%$ only) (Black: $1.0 \%$ only)]; (f) Postero-medial margin of posterior surface, middle $1 / 3$ shaft [(male: $4.8 \%$; female: $3.8 \%$ ) (Black: $8.7 \%$ only)]; (g) Postero-medial margin of posterior surface, proximal $1 / 3$ shaft [(female: $1.9 \%$ only) (Black: $1.9 \%$ only)]; (h) Postero-medial margin, middle 1/3 shaft [(male: 2.9\%; female: $5.8 \%$ ) (Black: 7.7\% only)]; (i) Postero-medial surface, middle $1 / 3$ shaft [(male: $4.8 \%$; female: $1.9 \%$ ) (Black: 6.7\% only)]; (j) Postero-medial surface, proximal $1 / 3$ shaft [(male: $1.0 \%$; female: $1.0 \%$ ) (Black: $1.9 \%$ only)]; (k) Antero-medial surface, middle 1/3 shaft [(male: 6.7\%; female: $3.8 \%$ ) (Black: $10.6 \%$ only)]; (l) Anteromedial surface, proximal 1/3 shaft [(male: $6.7 \%$; female: $1.0 \%$ ) (Black: $7.7 \%$ only)]; (m) Antero-medial surface, distal 1/3 shaft [(male: $1.0 \%$ only) (Black: $1.0 \%$ only)]; (n) Lateral surface, middle $1 / 3$ shaft [(male: $2.9 \%$; female: $1.0 \%$ ) (Black: $3.8 \%$ only)]; (o) Lateral surface, proximal 1/3 shaft [(male: $1.0 \%$; female: $1.0 \%$ ) (Black: $1.9 \%$ only)] (Figs. 1, 2 and 3; Table I).

Osteometry. The mean distance between the following fibular osteometric parameters were documented $(\mathrm{mm})$ : (i) Apex of fibular head and distal edge of nutrient foramen [(male: $166.75 \pm 38.27$; female: $147.20 \pm 22.48$ ) (Black: 158.31 \pm 33.82 ; Caucasian: 196.48 \pm 40.94 )]; (ii) Anterior and medial margins [(male: $5.79 \pm 1.92$; female: 5.24 \pm 1.47 ) (Black: 5.56 \pm 1.80 ; Caucasian: 6.33 \pm 1.16$)]$; (iii) Anterior and postero-medial margins [(male: 13.94 \pm 1.94 ; female: 12.72 \pm 2.65 ) (Black: 13.43 \pm 2.31 ; Caucasian: $15.18 \pm 0.13$ )]; (iv) Medial and postero-medial margins [(male: 9.62 \pm 1.69 ; female: 9.44 \pm 2.02$)$ (Black: 9.55 1.85; Caucasian: 9.67 \pm 0.13$)]$; (v) Anterior and postero-lateral margins [(male: 15.42 \pm 1.79 ; female:

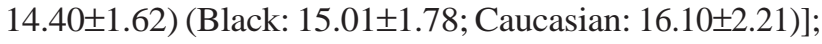


Fig. 1. Single nutrient foramen on lateral surface of proximal 1 13 of shaft. Key: HF= Head of fibula; I= Inferior; L= Lateral; $\mathrm{LS}=$ Lateral surface; $\mathrm{M}=$ Medial; $\mathrm{NF}=$ Nutrient foramen; $\mathrm{S}=$ Superior.

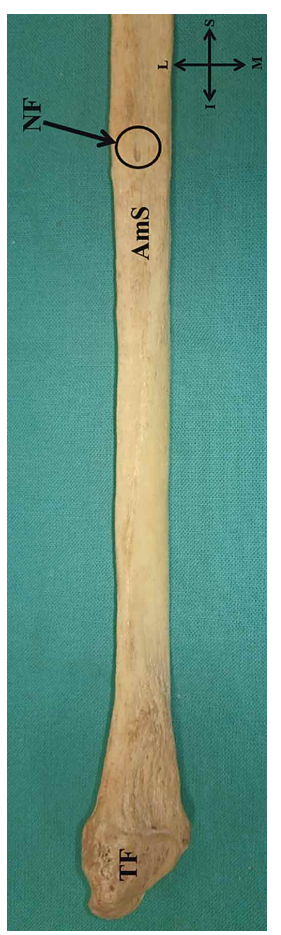

Fig. 2. Single nutrient foramen on anteromedial surface of middle $1 / 3$ of shaft. Key: AmS = Anteromedial surface; I= Inferior; $\mathrm{L}=$ Lateral; $\mathrm{M}=$ Medial; $\mathrm{NF}=$ Nutrient foramen; $\mathrm{S}=$ Superior; $\mathrm{TF}=$ Talar facet on distal fibula.
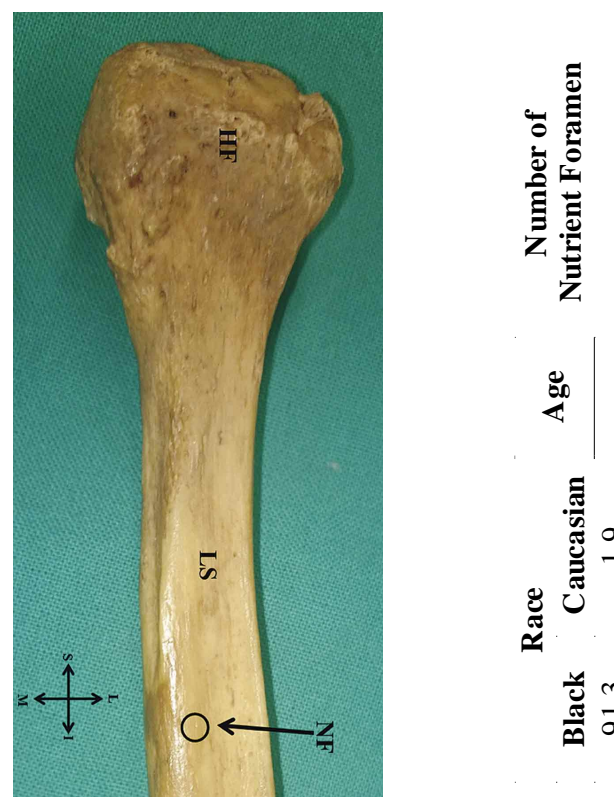

$\frac{5}{0}$

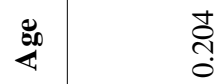

$\frac{\infty}{2}$

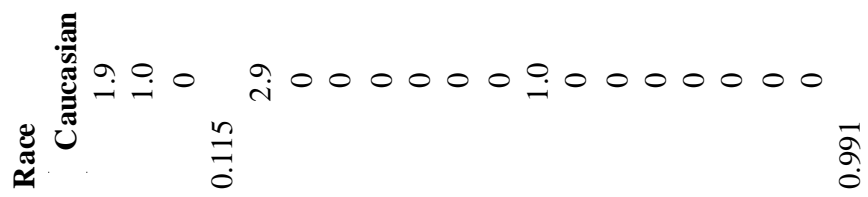

产
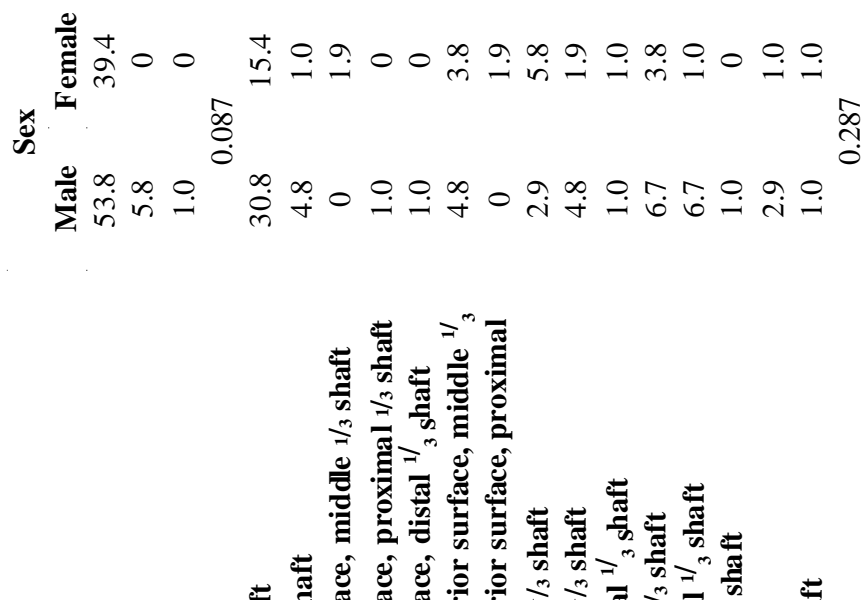

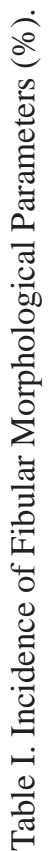

Fig. 3. Double nutrient foramina on posterior surface of middle $1 / 3$ of shaft. Key: I= Inferior; $\mathrm{L}=$ Lateral; $\mathrm{LM}=$ Lateral malleolus; $\mathrm{M}=$ Medial; $\mathrm{NF}=$ Nutrient foramen; $\mathrm{PS}=$ Posterior surface; $\mathrm{S}=$ Superior; $\mathrm{TF}=$ Talar facet on distal fibula. 


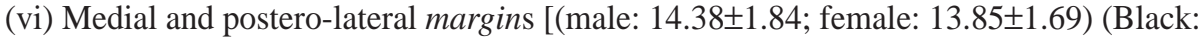
14.19 \pm 1.80 ; Caucasian: 14.13 \pm 1.95 )]; (vii) Postero-lateral and postero-medial margins

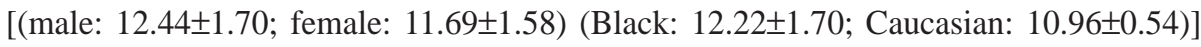
(Table II). The mean fibular length $(\mathrm{mm})$ and mean diameter of the nutrient foramen $(\mathrm{mm})$

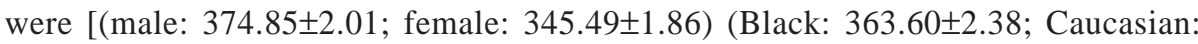
380.42 \pm 3.01$)$ ] and [(male: $1.00 \pm 0.34$; female: 0.96 \pm 0.42 ) (Black: 0.98 \pm 0.37 ; Caucasian: $1.11 \pm 0.27)$ ], respectively (Table II). The three sides of the triangular talar facet were recorded $(\mathrm{mm})$ : (i) Antero-medial distance [(male: 19.18 \pm 2.27 ; female: 18.39 \pm 2.22$)$ (Black: 18.88 \pm 2.29 ; Caucasian: 19.26 \pm 1.84 )]; (ii) Postero-medial distance [(male: 20.40 \pm 2.35 ; female: 18.21 \pm 2.15 ) (Black: 19.55 \pm 2.50 ; Caucasian: 21.11 \pm 2.43$)]$; (iii) Base [(male: 18.77 \pm 2.27 ; female: 17.14 \pm 1.50 ) (Black: 18.23 \pm 2.15 ; Caucasian: 16.72 \pm 2.38 )] (Table II). The relative angles between the sides of the talar facet were also calculated (o): (i) Angle between antero-medial and postero-medial distances [(male: 56.6; female: 55.7) (Black: 56.4; Caucasian: 48.6)]; (ii) Angle between postero-medial distance and base [(male: 58.5; female: 62.8) (Black: 59.9; Caucasian: 60.1)]; (iii) Angle between antero-medial distance and base [(male: 64.9; female: 61.6) (Black: 63.8; Caucasian: 71.4)] (Table II).

Statistically significant differences were documented between males and females for the following fibular osteometric parameters: (i) Distance between apex of fibular head and distal edge of nutrient foramen $(\mathrm{p}$ value $=0.001)$ (ii) Distance between anterior and postero-medial margins ( $\mathrm{p}$ value $=0.006$ ); (iii) Distance between anterior and posterolateral margins ( $\mathrm{p}$ value $=0.003$ ); (iv) Distance between postero-lateral and postero-medial margins $(\mathrm{p}$ value $=0.023)$; $(\mathrm{v})$ Fibular length $(\mathrm{p}$ value $=0.000) ;(\mathrm{vi})$ Postero-medial distance of talar facet ( $\mathrm{p}$ value $=0.000)$; (vii) Base of talar facet $(\mathrm{p}$ value $=0.000)($ Table II).
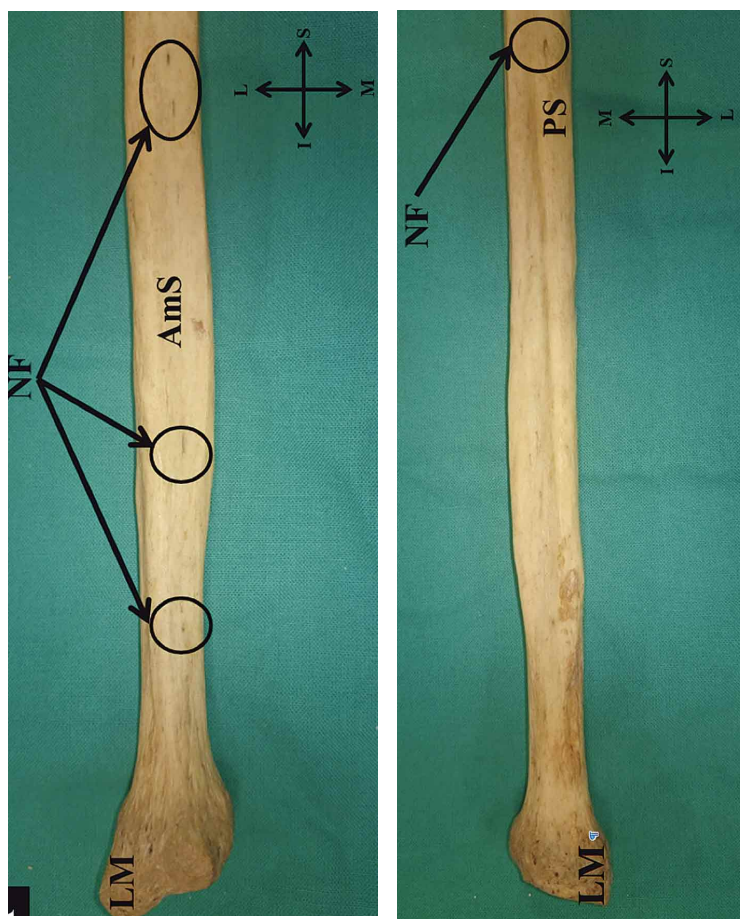

Fig. 4. Six nutrient foramina on fibular shaft: A. Anteromedial surface: Three foramina on middle $1 / 3$ of shaft and two foramina on proximal $1 / 3$ of shaft. B. One foramen on posterior surface of middle $1 / 3$ of shaft. Key: AmS=Anteromedial surface; $\mathrm{I}=$ Inferior; $\mathrm{L}=$ Lateral; $\mathrm{LM}=$ Lateral malleolus; $\mathrm{M}=$ Medial; $\mathrm{NF}=$ Nutrient foramen; $\mathrm{PS}=$ Posterior surface; $\mathrm{S}=$ Superior; $\mathrm{TF}=$ Talar facet on distal fibula.
Levels of statistical significance were recorded between age and the following fibular osteometric parameters: (i) Fibular length ( $p$ value $=$ 0.001 ); (ii) Diameter of nutrient foramen $(\mathrm{p}$ value $=$ 0.005); (iii) Distance between anterior and medial margins ( $\mathrm{p}$ value $=0.020$ ); (iv) Distance between anterior and posterolateral $\operatorname{margin} \mathrm{s}$ ( $\mathrm{p}$ value $=$ 0.000); (v) Distance between medial and postero-lateral margins ( $\mathrm{p}$ value $=0.010) ;(\mathrm{vi})$ Distance between postero-lateral and postero-medial margins $(\mathrm{p}$ value $=0.000)($ Table II $)$.

In addition, a statistically significant difference was determined between Black and Caucasian individuals for the distance between the apex of the fibular head and distal edge of the nutrient foramen $(\mathrm{p}$ value $=$ 0.030) (Table II).

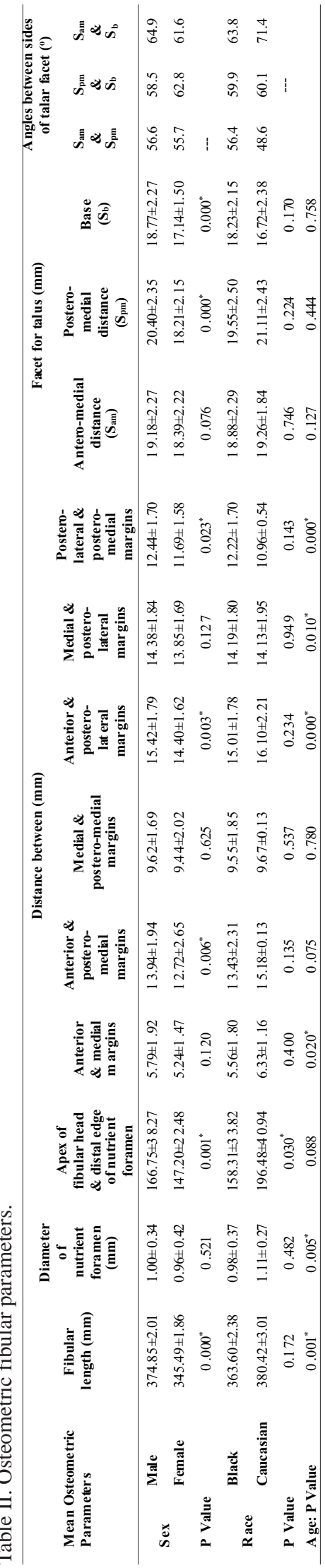




\section{DISCUSSION}

Apart from its shape-shift ability and morphometric consistency, the fibula appears to be superior to any other bone group as it allows for a reduction in operative time (Matsuura et al., 1999). Since the fibula is considered to provide an osseous platform for the prosthetic restoration of an individual, osteometric and morphological data pertaining to the fibula may prove pivotal for reconstruction following disarticulation and fracture (Fernandes; Taser et al.; Nguyen \& Lin, 2011).

Number of Nutrient Foramina. According to Ellis (2006), long bones typically bear one or two nutrient foramina. The presence and location of nutrient foramina is especially important for the vascularization of the fibular shaft as the survival of osteophytes in pathological cases is dependent on an ample nutrient blood flow (Pereira et al.). Although, the presence of double and six nutrient foramina were identified, a single nutrient foramen appeared to be most prevalent in the present study (Table I). This was in accordance with the findings of Pereira et al. who reported the presence of one nutrient foramen in $99.13 \%$ of fibulae. In this study the presence of six nutrient foramina was observed on a single Black male fibula only (1\%) (Table I). Similarly, double nutrient foramina were also most prominent in Black male fibulae (Table I). This appears to be a unique observation as it has not been reported previously. These relatively minute values of double nutrient foramina corroborated the findings of Gümüsburun et al. (1994), Kizilkant et al. (2007) and Pereira et al., who documented values of $5.4 \%, 11.6 \%$ and $0.87 \%$, respectively.

Location of Nutrient Foramina. In light of the reported variation regarding the precise location of the fibular nutrient foramina within the relative surfaces, the current study identified the nutrient foramina to be present on four different fibular surfaces, viz. posterior, postero-medial, antero-medial and lateral, in relation to the respective fibular margins and component parts (Table I). The nutrient foramina were predominantly located on the posterior fibular surface in relation to the middle $1 / 3$ of the shaft, an observation that was formerly noted by Matsuura et al. and Pereira et al.. This was in accordance with the studies conducted by Shimada \& Yoshimura and Chen et al., who noticed that nutrient foramina were most prevalent within the middle 1/ 3 of the fibular shaft. In this study, nutrient foramina were found to be situated within the medial and lateral fibular surfaces, which corroborated the findings of Matsuura et al. and Pereira et al., respectively. The presence of nutrient foramina along the medial fibular margin appeared to be a frequent occurrence which was also seen by Matsuura et al.
The current study revealed the presence of nutrient foramina within the component parts of the antero-medial fibular surface, a finding that has not been documented in the literature reviewed. Such statistical data regarding the distribution of nutrient foramina may suggest safe osseous selection levels thus preventing disruption of the nutrient blood flow during placement procedures (Corner, 1913; Pereira et al.).

Osteometry. Despite the conventional use of the Body-Mass Index to determine the nutritional status of an individual, it is considered to be rather impractical in the aged (Auyeung $e t$ $a l$.). As the height of the older population decreases with vertebral column shrinkage, the Body-Mass Index may overstate the actual nutritional status of the patient (Auyeung et al.). Since the fibula is composed of distinguishable anatomical landmarks that are seldom affected by arthritic symptoms, this study placed special emphasis on the osteometric architecture of the fibula. In light of the lack of fibular osteometric data and norms regarding population demographics, the present study focused extensively on the fibular osteometry.

With the exception of the angle between the anteromedial side and base of the triangular talar facet, the remaining fibular osteometric parameters were larger in males (Table II). The statistically significant $\mathrm{p}$ values recorded for the comparison of sex with a number of osteometric parameters may suggest that male individuals generally present with larger fibular osteometry values (Table II). This was in accordance with the findings of Auyeung $e t$ al., who reported the fibular length to be $360.00 \pm 1.7 \mathrm{~mm}$ and $320.00 \pm 1.8 \mathrm{~mm}$ in males and females, respectively.

Although the distances between the medial and postero-lateral margins, postero-lateral and postero-medial margins, base of talar facet and the angle between the postero-medial and antero-medial sides of the talar facet were markedly greater in Black individuals, larger fibular osteometry values appeared to be a characteristic in Caucasian individuals (Table II). The correlation of race with the distance between the apex of the fibular head and distal edge of the nutrient foramen yielded a statistically significant difference of 0.030 indicating that this osteometric parameter is classically larger in Caucasian individuals (Table II).

Consequently, the comparison of age with six of the fibular osteometric parameters resulted in statistically significant $p$ values. This may account for the ability of the fibula to withstand degenerative age-related changes that are generally a common phenomenon of long bone osteometry. 


\section{CONCLUSION}

Since this study documented several locations of the nutrient foramen within the fibular shaft, it may lead to the development of a simple classification scheme providing appropriate sites for the harvesting of grafts. The standard fibular osteometry investigated in this study are novel and unique as previous studies have only reported on the fibular length. As the osseous platform of preference, the fibular osteometry and morphology may assist in the determination of height and other nutritional parameters. In addition, the osteometry of the talar facet may lead to advances in the operative management and design of prosthetics regarding the talocrural joint. The consideration of specific South African demographic factors may represent a potential platform for the introduction of standard norms and fibular models.

NAIDOO, N.; ISHWARKUMAR, S.; LAZARUS, L.; PILLAY, P. \& SATYAPAL, K. S. Osteometría y morfología de la fíbula humana: Un estudio de Sudáfrica. Int. J. Morphol., 33(3):1071-1077, 2015.

RESUMEN: A partir de estudios recientes se ha considerado al colgajo de fíbula como punto de referencia para la reconstrucción y el tratamiento de lesiones y heridas compuestas. Debido a su ubicación postero-lateral en la pierna, la aplicación del colgajo de fíbula se considera estéticamente ventajoso ya que la cicatriz del sector donante puede ser disimulada fácilmente. Anatómicamente, en la fíbula se puede reconocer una diáfisis y dos extremos. Este estudio tuvo como objetivo investigar la morfología del foramen nutricio y la osteometría relativa de la fíbula. Se realizó una evaluación osteométrica y morfológica de 104 fíbulas humanas secas, pertenecientes a hombres y mujeres de grupos de población de raza negra y caucásica, nativos de Sudáfrica (rango de edad: 15-81 años). Se observó la presencia de forámenes nutricios individuales, dobles y en número de seis. Se identificaron un total de 15 sitios diferentes de ubicación del foramen nutricio en relación con las superficies, márgenes y demás componentes de la fíbula. Otros parámetros osteométricos como longitud media de la fíbula ( $\mathrm{mm}$ ) fueron: $374,85 \pm 2,01$ en hombres y 345,49 $\pm 1,86$ en mujeres,

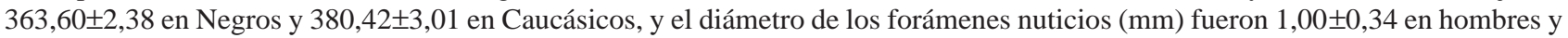
0,96 $\pm 0,42$ en mujeres, 0,98 $\pm 0,37$ en Negros y 1,11 $\pm 0,27$ en Caucásico, respectivamente. Debido a la falta de datos osteométricos respecto a la desestabilización y la posterior reconstrucción de la articulación talocrural, se cuantificaron los lados relativos y los ángulos de la faceta triangular irregular del talus. Debido a la correlación de los respectivos parámetros de la fíbula con la edad, sexo y razas, el foco de este estudio fue extenso en comparación con los estudios anteriores. Las diferencias estadísticamente significativas para la edad, el sexo y la raza pueden sugerir una estandarización en Sudáfrica de esos factores demográficos con los parámetros pertenecientes a la fíbula. Por otra parte, la ubicación de los forámenes nutricios dentro del eje de la fíbula puede ayudar con la el desarrollo de sistemas de clasificación simples para la recolección de los injertos de fíbula.

PALABRAS CLAVE: Fíbula; Osteometría; Morfología; Foramen Nutricio.

\section{REFERENCES}

Achterman, C. \& Kalamchi, A. Congenital deficiency of the fibula. J. Bone Joint Surg. Br., 61-B(2):133-7, 1979.

Auyeung, T. W.; Lee, J. S.; Kwok, T.; Leung, J.; Leung, P. C. \& Woo, J. Estimation of stature by measuring fibula and ulna bone length in 2443 older adults. J. Nutr. Health Aging, 13(10):931-6, 2009.

Chen, Y. L.; Shen, Z. W.; Bao, G. Z. \& Tang, S. The vascular supply of the fibula. Acta Anat. Sin., 12(1):13-8, 1981.

Corner, E. M. The clinical picture of congenital absence of the fibula. Br. J. Surg., 1(2):203-6, 1913.

Ellis, H. Clinical Anatomy. 11th ed. Oxford, Blackwell Publishing, 2006. pp.224-5.

Fernandes, R. Fibula free flap in mandibular reconstruction. Atlas Oral Maxillofac. Surg. Clin. North Am., 14(2):143-50, 2006.
Gray, H. Anatomy of the Human Body. Philadelphia, Lea \& Febiger, 1918; Bartleby.com, 2000. Available from: www.bartleby.com/107/

Gümüsburun, E.; Yücel, F.; Ozkan, Y. \& Akgün, Z. A study of the nutrient foramina of lower limb long bones. Surg. Radiol. Anat., 16(4):409-12, 1994.

Kizilkanat, E.; Boyan, N.; Ozsahin, E. T.; Soames, R. \& Oguz, O. Location, number and clinical significance of nutrient foramina in human long bones. Ann. Anat., 189(1):87-95, 2007.

Matsuura, M.; Ohno, K.; Michi, K.; Egawa, K. \& Takiguchi, R. Clinicoanatomic examination of the fibula: anatomic basis for dental implant placement. Int. J. Oral Maxillofac. Implants, 14(6):879-84, 1999.

Moore, K. L.; Dalley, A. F. \& Agur, A. M. R. Clinically Oriented 
NAIDOO, N.; ISHWARKUMAR, S.; LAZARUS, L.; PILlAY, P. \& SATYAPAL, K. S. Osteometry and morphology of the human fibula: A South African study. Int. J. Morphol., 33(3):1071-1077, 2015.

Anatomy. 6th ed. Baltimore, Walters Kluwer/Lippincott Williams \& Wilkins, 2010. pp.521-2.

Nguyen, D. H. \& Lin, C. H. How to harvest a fibula flap in 45 minutes. Plast. Surg. Pulse News, 3(2), 2011. Available from: http://www.plasticsurgerypulsenews.com/7/ article_dtl.php?QnCategoryID=66\&QnArticleID=146\&QnCurPage=1

Pereira, G. A. M.; Lopes, P. T. C.; Santos, A. M. P. V. \& Silveira, F. H. S. Nutrient Foramina in the Upper and Lower Limb Long Bones: Morphometric Study in Bones of Southern Brazilian Adults. Int. J. Morphol., 29(2):514-20, 2011.

Shimada, T. \& Yoshimura, M. Anatomical and clinical studies on peroneal vascularized composite tissue transfer. Nihon Seikeigeka Gakkai Zasshi, 63(12):1452-63, 1989.

Skinner, H. A. The Origin of Medical Terms. 2nd ed. Baltimore, The Williams and Wilkins Co., 1961.

Standring, S. Gray's Anatomy: The Anatomical Basis of Clinical Practice. 40th ed. Madrid, Elsevie, 2008. pp.830-2, 838-40, 841-5.

Taser, F.; Toker, S. \& Kilincoglu, V. Evaluation of morphometric characteristics of the fibular incisura on dry bones. Eklem Hastalik Cerrahisi, 20(1):52-8, 2009.

Taylor, G. I.; Miller, G. D. \& Ham, F. J. The free vascularized bone graft. A clinical extension of microvascular techniques. Plast. Reconstr. Surg., 55(5):533-44, 1975.

Winters, H. A. H. Vascularized bone of fibula and iliac crest. A single surgeon's experience of more than 10 years. Thesis $\mathrm{PhD}$. Amsterdam, Vrije Universiteit Amsterdam, 2007. pp.9106.

\author{
Correspondence to: \\ Professor KS Satyapal \\ Department of Clinical Anatomy \\ School of Laboratory Medicine and Medical Sciences \\ College of Health Sciences \\ University of KwaZulu-Natal \\ Private Bag X54001 \\ Durban, 4000 \\ SOUTH AFRICA \\ Email address:satyapalk@ukzn.ac.za
}

Received: 13-04-2015

Accepted: 15-07-2015 